\title{
Palladium(II)-catalyzed oxidation of L-tryptophan by hexacyanoferrate(III) in perchloric acid medium: a kinetic and mechanistic approach
}

\author{
AHMED FAWZY ${ }^{\mathrm{a}, \mathrm{b}, *}$ \\ ${ }^{a}$ Chemistry Department, Faculty of Applied Sciences, Umm Al-Qura University, Makkah, Saudi Arabia \\ ${ }^{\mathrm{b}}$ Chemistry Department, Faculty of Science, Assiut University, Assiut, Egypt \\ e-mail: afsaad13@yahoo.com
}

MS received 9 July 2015; revised 27 October 2015; accepted 21 November 2015

\begin{abstract}
The catalytic effect of palladium(II) on the oxidation of L-tryptophan by potassium hexacyanoferrate(III) has been investigated spectrophotometrically in aqueous perchloric acid medium. A first order dependence in [hexacyanoferrate(III)] and fractional-first order dependences in both [L-tryptophan] and [palladium(II)] were obtained. The reaction exhibits fractional-second order kinetics with respect to $\left[\mathrm{H}^{+}\right]$. Reaction rate increased with increase in ionic strength and dielectric constant of the medium. The effect of temperature on the reaction rate has also been studied and activation parameters have been evaluated and discussed. Initial addition of the reaction product, hexacyanoferrate(II), does not affect the rate significantly. A plausible mechanistic scheme explaining all the observed kinetic results has been proposed. The final oxidation products are identified as indole-3-acetaldehyde, ammonium ion and carbon dioxide. The rate law associated with the reaction mechanism is derived.
\end{abstract}

Keywords. Kinetics; oxidation; L-tryptophan; hexacyanoferrate(III); palladium(II).

\section{Introduction}

A large number of kinetic investigations on the oxidation of amino acids are being carried out using various oxidants under different experimental conditions ${ }^{1-16}$ because of their biological significance, selectivity towards the oxidants and to understand the mechanism of such biological redox reactions. In many cases,,${ }^{5-14}$ it was reported that amino acids undergo oxidative decarboxylation and deamination. L-Tryptophan (Trp) is one of the essential amino acids that is required in human diet. It is a reducing agent in chemical and biochemical systems. The rate of reduction depends on the oxidant and $\mathrm{pH}$ of the medium. Our literature survey reveals that the kinetic studies on the oxidation of L-tryptophan by different oxidants have received limited attention. ${ }^{10-16}$

The most important iron(III) cyanide complex is the hexacyanoferrate(III) anion ( $\mathrm{HCF}),\left[\mathrm{Fe}(\mathrm{CN})_{6}\right]^{3-}$, in which the $\mathrm{Fe}^{3+}$ center is bound in octahedral geometry to six cyanide ligands. Hexacyanoferrate(III) is an efficient one-electron oxidant and has been observed to be a "substitution inert-transition metal complex". ${ }^{17}$ Oxidation by HCF in alkaline medium is well understood, for organic ${ }^{17-23}$ and inorganic ${ }^{24-30}$ compounds. Its usefulness may be due to its unequivocal stability, water

*For correspondence solubility, single equivalent change and its moderate reduction potential of $0.45 \mathrm{~V}$, leading to its reduction to hexacyanoferrate(II), a stable product. In addition, it adds less error to the experimental results, and the data can be analyzed meticulously to establish the reaction path. On the other hand, studies involving HCF as an oxidant in acid media are limited. ${ }^{28-33}$ Furthermore, hexacyanoferrate(III) is very sensitive to the solvent and acidity and forms different intermediate species in acid media. $^{28}$

It was shown by the previous workers that the oxidation of amino acids by hexacyanoferrate(III) proceeds very slowly in the absence of a catalyst while it follows a complex kinetics in the presence of it. ${ }^{34}$ Transition metals are known to catalyze many oxidation-reduction reactions because they involve multiple oxidation states. In recent years, the use of transition metal ions such as ruthenium, osmium, palladium, manganese, chromium, and iridium, either alone or as binary mixtures, as catalysts in various redox processes has attracted considerable interest. ${ }^{35}$ Although the mechanism of the catalysis depends on the nature of the substrates, oxidant and experimental conditions, it has been shown ${ }^{36}$ that metal ions acts as catalysts by one of several different paths such as formation of complexes with reactants, oxidation of substrates themselves or through formation of free radicals. 
No work, however, has been reported on the oxidation of L-tryptophan by hexacyanoferrate(III) in acid medium in either absence or presence of a catalyst. The present report deals with the title reaction in order to understand the active species of oxidant and catalyst, to check the reactivity of L-tryptophan towards hexacyanoferrate(III) in perchloric acid medium, to examine the catalytic activity of the catalyst and to propose an appropriate reaction mechanism.

\section{Experimental}

\subsection{Materials}

All the chemicals employed in the present work were of reagent grade and their solutions were prepared by dissolving the requisite amounts of the samples in doubly distilled water. A stock solution of L-tryptophan (E. Merck, US) was prepared afresh by dissolving the amino acid sample in bidistilled water. A fresh solution of hexacyanoferrate(III) was prepared by dissolving potassium hexacyanoferrate(III) (BDH, USA) in water and its concentration was ascertained by iodometric titration. ${ }^{37 a}$ Hexacyanoferrate(II) solution was prepared by dissolving potassium hexacyanoferrate(II) (SD Fine Chemicals, India; Aldrich, USA) in water and standardizing it with cerium(IV) solution. ${ }^{37 \mathrm{~b}}$ The Palladium(II) chloride solution was prepared by dissolving a known weight of the sample (SD Fine Chemicals) in hydrochloric acid and stored in a black coated bottle to prevent any photochemical deterioration. Perchloric acid and sodium perchlorate were used to vary the acid concentration and ionic strength in the reaction medium, respectively.

\subsection{Kinetic measurements}

The kinetic runs were carried out under pseudo-first order conditions keeping L-tryptophan always in excess over hexacyanoferrate(III) concentration at a constant ionic strength of $3.0 \mathrm{~mol} \mathrm{dm}^{-3}$ and at a constant temperature of $(25 \pm 0.1)^{\circ} \mathrm{C}$ unless otherwise stated. The progress of the reaction was followed spectrophotometrically by monitoring the decrease in the absorbance of $\mathrm{HCF}$ at its absorption maximum, $\lambda_{\max }=420 \mathrm{~nm}$, as a function of time using Shimadzu UV-VIS-NIR3600 double-beam spectrophotometer keeping the cell compartment at constant temperature. Solutions of the oxidant and the mixture containing L-tryptophan substrate, perchloric acid and palladium(II) chloride catalyst were separately thermostated for nearly $30 \mathrm{~min}$. The oxidant was then added to the mixture, the overall reaction mixture was transferred to the cell of path length $1 \mathrm{~cm}$, and 3-4 experimental readings were taken in each run. It was observed that the oxidation reaction did not proceed in the absence of palladium(II) catalyst. Good straight lines for $\ln$ (absorbance) versus time plots were obtained for about $85 \%$ of the reaction completion and the pseudo-first order rate constant values $\left(k_{\mathrm{C}}\right)$ were calculated as the gradients of such plots. The rate constants were reproducible to within $4 \%$.

\section{Results and Discussion}

\subsection{Stoichiometry and product analysis}

Reaction mixtures containing varying ratios of hexacyanoferrate(III) to L-tryptophan in $2.0 \mathrm{~mol} \mathrm{dm}^{-3}$ perchloric acid at a constant ionic strength of $3.0 \mathrm{~mol}$ $\mathrm{dm}^{-3}$ were kept for over $24 \mathrm{~h}$ at $25^{\circ} \mathrm{C}$ in a closed vessel for completion of the reaction. The unreacted $[\mathrm{HCF}]$ was analyzed spectrophotometrically by measuring its absorption at $420 \mathrm{~nm}$. The results indicated that two moles of HCF are consumed by one mole of Ltryptophan to yield the oxidation products as shown in the following stoichiometric equation (1),

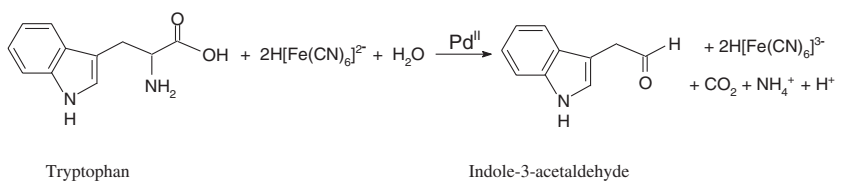

The product obtained was tested for the aldehyde, indole-3-acetaldehyde by TLC. One spot was obtained when the chromatogram was assayed with 2,4-dinitrophenylhydrazine. An aliquot $(5 \mathrm{~mL})$ was pipetted into $50 \mathrm{~mL}$ of $2.0 \mathrm{~N} \mathrm{HCl}$ saturated with 2,4-dinitrophenylhydrazine which was filtered, washed, dried and weighed. The yield was calculated from the amount of 2,4-dinitrophenylhydrazone formed and was found to about $84 \%$. Further proof of the formation of the corresponding aldehyde was obtained by isolating the aldehyde using the standard method. ${ }^{38}$ The byproducts were identified as ammonia by Nessler's reagent ${ }^{39}$ and carbon dioxide by limewater. Similar oxidation products with different experimental conditions have been also reported earlier. ${ }^{10-16}$

\subsection{Spectroscopic changes}

The spectroscopic changes associated with the palladium(II)-catalyzed oxidation of L-tryptophan by hexacyanoferrate(III) in perchloric acid medium are shown in figure 1 . The scanned spectra shown in figure 1a indicate gradual disappearance of $\mathrm{HCF}(\mathrm{III})$ band located at $\lambda=420 \mathrm{~nm}$ with time as a result 

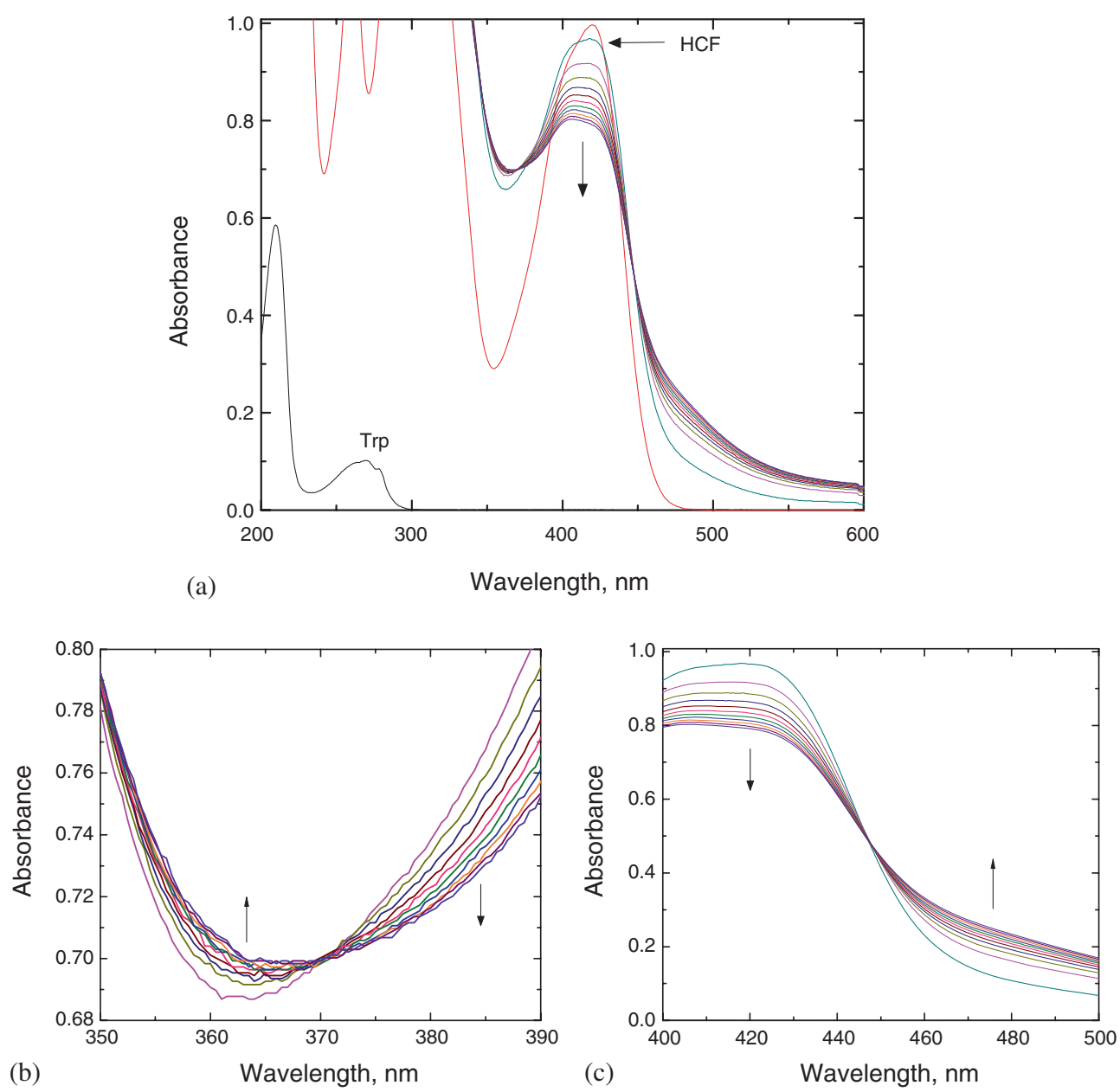

Figure 1. (a) Spectroscopic changes associated with palladium(II)-catalyzed oxidation of L-tryptophan by hexacyanoferrate(III) in perchloric acid medium. (b, c) Careful examination of the spectroscopic changes around the two isosbestic points. $[\mathrm{Trp}]=0.01,[\mathrm{HCF}]=7.0$ $\times 10^{-4},\left[\mathrm{H}^{+}\right]=2.0,\left[\mathrm{Pd}^{\mathrm{II}}\right]=5.0 \times 10^{-5}$ and $I=3.0 \mathrm{~mol} \mathrm{dm}{ }^{-3}$ at $25^{\circ} \mathrm{C}$. Scan time intervals $=2 \mathrm{~min}$.

of its reduction to $\mathrm{HCF}(\mathrm{II})$. A careful examination of the spectroscopic changes, figure $1 \mathrm{~b}$ and $\mathrm{c}$, manifests a simultaneous growing of an absorption band located above $445 \mathrm{~nm}$ and exhibit two isosbestic points centered at wavelengths 370 and $444 \mathrm{~nm}$. These spectroscopic features are consistent with the formation of an adduct between palladium(II) catalyst and L-tryptophan substrate.

\subsection{Reaction orders}

The reaction orders with respect to the reactants were determined from plots of $\log k_{\mathrm{C}}$ versus $\log$ (conc.) by varying the concentrations of L-tryptophan substrate, perchloric acid and palladium(II) chloride catalyst, in turn, while keeping the others constant.

The effect of $[\mathrm{HCF}]$ on the rate of reaction was studied by varying its concentration in the range $3.0 \times 10^{-4}$ to $11.0 \times 10^{-4} \mathrm{~mol} \mathrm{dm}{ }^{-3}$ at fixed $[\mathrm{Trp}],\left[\mathrm{H}^{+}\right],\left[\mathrm{Pd}^{\mathrm{II}}\right]$ and ionic strength and temperature. The order with respect to $[\mathrm{HCF}]$ was found to be unity, as plots of $\ln$ [absorbance] against time were linear with no variation in the slope for different $[\mathrm{HCF}]$ as shown in table 1.

The rate constant was determined at different initial concentrations of the reductant L-tryptophan keeping all other reactant concentrations constant including palladium(II) catalyst. It was found that the rate of reaction increased with increasing the concentration of Ltryptophan as listed in table 1 . The plot of $k_{\mathrm{C}}$ versus [Trp], figure 2, gave a good straight line with a positive intercept on $k_{\mathrm{C}}$ axis suggesting that the order of reaction with respect to [Trp] is less than unity.

At constant ionic strength of $3.0 \mathrm{~mol} \mathrm{dm}^{-3}$ and other conditions remaining constant, perchloric acid was varied from 1.0 to $3.0 \mathrm{~mol} \mathrm{dm}^{-3}$. It was noticed that as $\left[\mathrm{H}^{+}\right]$increased the rate of reaction increased (table 1) with a fractional-second order as indicated by the plot of $k_{\mathrm{C}}$ versus $\left[\mathrm{H}^{+}\right]^{2}$ (figure 3 ). 
Table 1. Effect of variation of $[\mathrm{HCF}],[\mathrm{Trp}],\left[\mathrm{H}^{+}\right],\left[\mathrm{Pd}^{\mathrm{II}}\right]$ and ionic strength, $I$, on the pseudo-first order rate constant $\left(k_{\mathrm{C}}\right)$ in the paladium(II)-catalyzed oxidation of L-tryptophan by hexacyanoferrate(III) in perchloric acid medium at $25^{\circ} \mathrm{C}$.

\begin{tabular}{|c|c|c|c|c|c|}
\hline $\begin{array}{l}10^{4}[\mathrm{HCF}] \\
\left(\mathrm{mol} \mathrm{dm}^{-3}\right)\end{array}$ & $\begin{array}{c}10^{2}[\mathrm{Trp}] \\
(\mathrm{mol} \mathrm{dm}-3)\end{array}$ & $\begin{array}{c}{\left[\mathrm{H}^{+}\right]} \\
\left(\mathrm{mol} \mathrm{dm} \mathrm{dm}^{-3}\right)\end{array}$ & $\begin{array}{c}10^{5}\left[\mathrm{Pd}^{\mathrm{II}}\right] \\
(\mathrm{mol} \mathrm{dm}-3)\end{array}$ & $\begin{array}{c}I \\
\left(\mathrm{~mol} \mathrm{dm} \mathrm{dm}^{-3}\right)\end{array}$ & $\begin{array}{c}10^{4} k_{C} \\
\left(\mathrm{~s}^{-1}\right)\end{array}$ \\
\hline 3.0 & 1.0 & 2.0 & 5.0 & 3.0 & 22.1 \\
\hline 5.0 & 1.0 & 2.0 & 5.0 & 3.0 & 23.2 \\
\hline 7.0 & 1.0 & 2.0 & 5.0 & 3.0 & 22.8 \\
\hline 9.0 & 1.0 & 2.0 & 5.0 & 3.0 & 23.5 \\
\hline 11.0 & 1.0 & 2.0 & 5.0 & 3.0 & 22.7 \\
\hline 7.0 & 0.3 & 2.0 & 5.0 & 3.0 & 9.6 \\
\hline 7.0 & 0.5 & 2.0 & 5.0 & 3.0 & 14.1 \\
\hline 7.0 & 1.0 & 2.0 & 5.0 & 3.0 & 22.8 \\
\hline 7.0 & 2.0 & 2.0 & 5.0 & 3.0 & 39.8 \\
\hline 7.0 & 3.0 & 2.0 & 5.0 & 3.0 & 53.7 \\
\hline 7.0 & 1.0 & 1.0 & 5.0 & 3.0 & 6.6 \\
\hline 7.0 & 1.0 & 1.5 & 5.0 & 3.0 & 13.8 \\
\hline 7.0 & 1.0 & 2.0 & 5.0 & 3.0 & 22.8 \\
\hline 7.0 & 1.0 & 2.5 & 5.0 & 3.0 & 34.5 \\
\hline 7.0 & 1.0 & 3.0 & 5.0 & 3.0 & 47.7 \\
\hline 7.0 & 1.0 & 2.0 & 1.0 & 3.0 & 7.7 \\
\hline 7.0 & 1.0 & 2.0 & 3.0 & 3.0 & 15.5 \\
\hline 7.0 & 1.0 & 2.0 & 5.0 & 3.0 & 22.8 \\
\hline 7.0 & 1.0 & 2.0 & 7.0 & 3.0 & 30.8 \\
\hline 7.0 & 1.0 & 2.0 & 9.0 & 3.0 & 40.0 \\
\hline 7.0 & 1.0 & 2.0 & 5.0 & 3.0 & 22.8 \\
\hline 7.0 & 1.0 & 2.0 & 5.0 & 3.3 & 23.3 \\
\hline 7.0 & 1.0 & 2.0 & 5.0 & 3.6 & 24.1 \\
\hline 7.0 & 1.0 & 2.0 & 5.0 & 4.0 & 25.0 \\
\hline 7.0 & 1.0 & 2.0 & 5.0 & 4.5 & 25.9 \\
\hline
\end{tabular}

Experimental error $\pm 4 \%$.

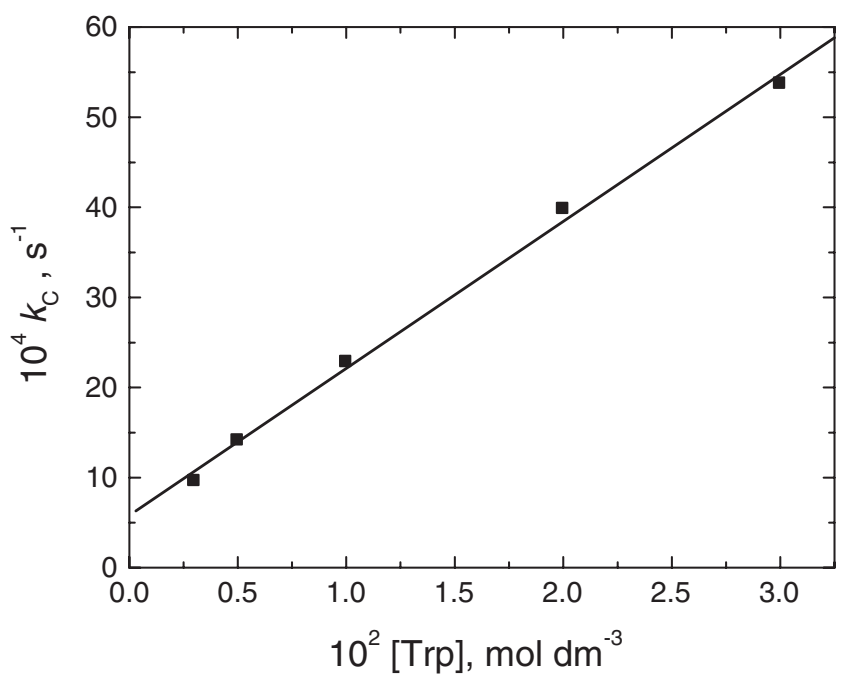

Figure 2. Plot of $k_{\mathrm{C}}$ vs [Trp] in the paladium(II)-catalyzed oxidation of L-tryptophan by hexacyanoferrate(III) in perchloric acid medium. $[\mathrm{HCF}]=7.0 \times 10^{-4},\left[\mathrm{H}^{+}\right]=2.0,\left[\mathrm{Pd}^{\mathrm{II}}\right]$ $=5.0 \times 10^{-5}$ and $I=3.0 \mathrm{~mol} \mathrm{dm}^{-3}$ at $25^{\circ} \mathrm{C}$.

The palladium(II) catalyst concentration was varied from $1.0 \times 10^{-5}$ to $9.0 \times 10^{-5} \mathrm{~mol} \mathrm{dm}^{-3}$ at constant concentrations of Trp, $\mathrm{HCF}, \mathrm{H}^{+}$and at constant ionic

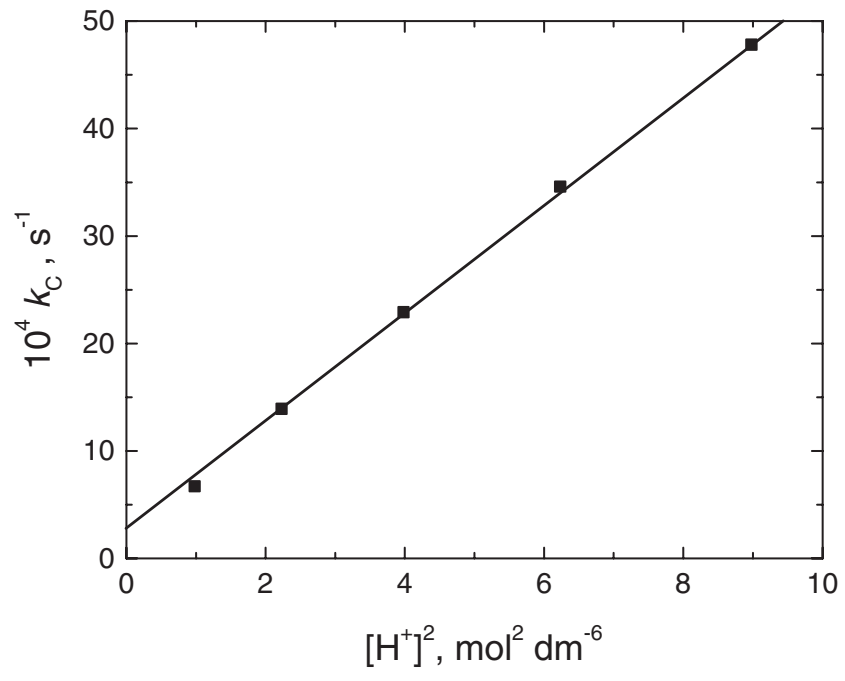

Figure 3. Plot of $k_{\mathrm{C}}$ versus $\left[\mathrm{H}^{+}\right]^{2}$ in the paladium(II)catalyzed oxidation of L-tryptophan by hexacyanoferrate(III) in perchloric acid medium. [Trp] $=0.01,[\mathrm{HCF}]=7.0$ $\times 10^{-4},\left[\mathrm{Pd}^{\mathrm{II}}\right]=5.0 \times 10^{-5}$ and $I=3.0 \mathrm{~mol} \mathrm{dm}^{-3}$ at $25^{\circ} \mathrm{C}$.

strength and temperature. Reaction rate was found to increase with increasing $\left[\mathrm{Pd}^{\mathrm{II}}\right]$ (table 1 ). The order was found to be less than unity as shown in figure 4 . 


\subsection{Effect of ionic strength and dielectric constant}

The effect of ionic strength was studied in the concentration range $3.0-4.5 \mathrm{~mol} \mathrm{dm}^{-3}$ at constant $[\mathrm{HCF}]$, $[\mathrm{Trp}],\left[\mathrm{Pd}^{\mathrm{II}}\right],\left[\mathrm{H}^{+}\right]$and temperature by varying the concentration of $\mathrm{NaClO}_{4}$. The results are presented in table 1. These results show that the pseudo-first order rate constant $k_{\mathrm{C}}$ increased with increasing ionic strength of the medium and the Debye-Hückel plot was found to be linear with a positive slope, figure $5 \mathrm{a}$.

In order to determine the effect of dielectric constant $(D)$ of the medium on the rate, the oxidation of L-tryptophan by HCF was studied at different solvent compositions (v/v) of acetic acid and water. The dielectric constant of the medium at different compositions was calculated using dielectric constants of water and

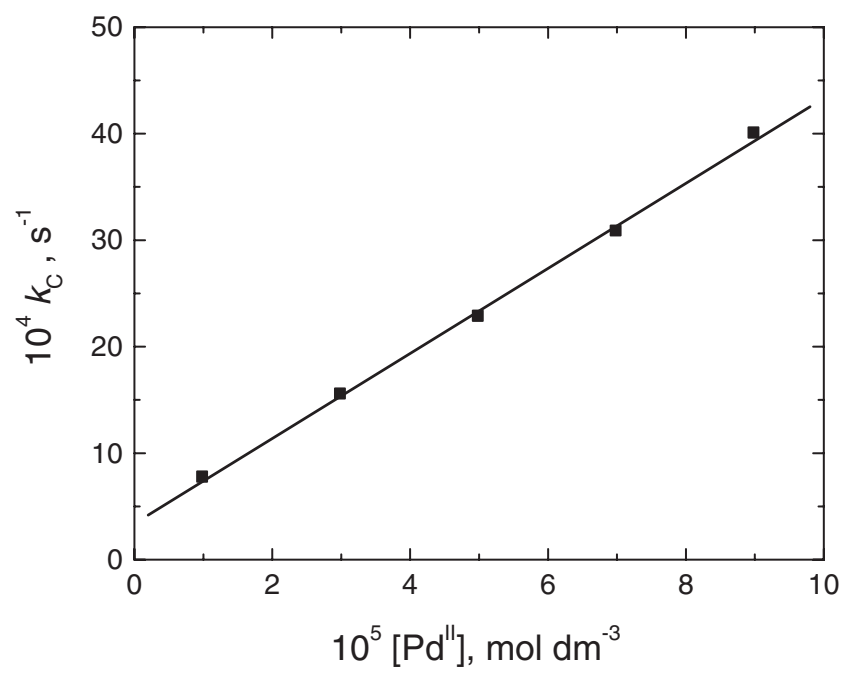

Figure 4. Plot of $k_{\mathrm{C}}$ versus $\left[\mathrm{Pd}^{\mathrm{II}}\right]$ in the paladium(II)catalyzed oxidation of L-tryptophan by hexacyanoferrate(III) in perchloric acid medium. $[\mathrm{Trp}]=0.01,[\mathrm{HCF}]=7.0 \times$ $10^{-4},\left[\mathrm{H}^{+}\right]=2.0$ and $I=3.0 \mathrm{~mol} \mathrm{dm}{ }^{-3}$ at $25^{\circ} \mathrm{C}$.

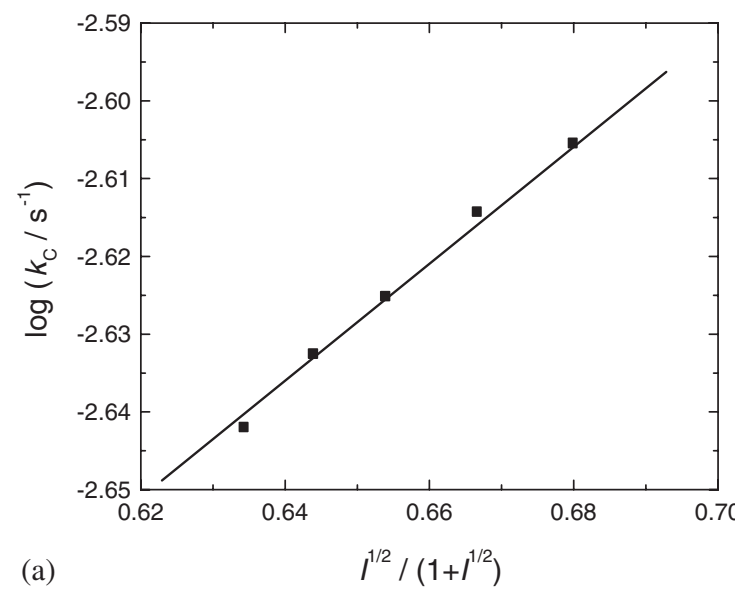

(a)

$$
l^{1 / 2} /\left(1+l^{1 / 2}\right)
$$

(b)

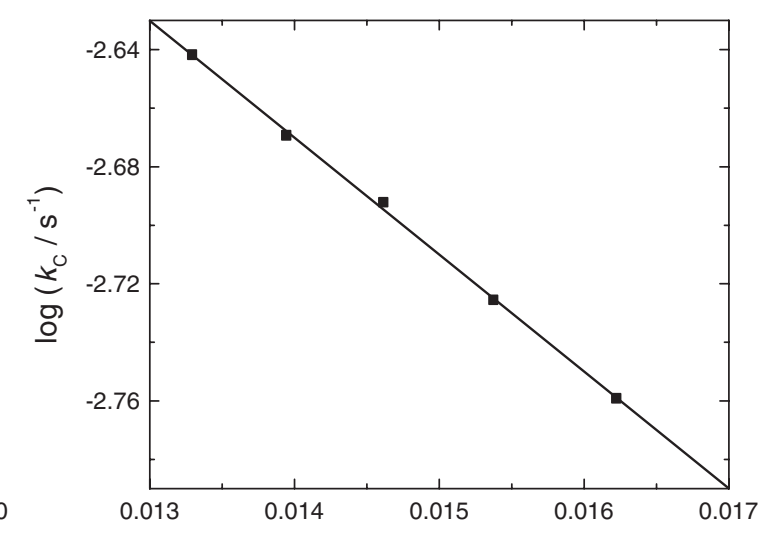

\subsection{Effect of temperature}

The kinetics was studied at different temperatures, 288, 293, 298, 303 and $308 \mathrm{~K}$, at constant concentrations of

Figure 5. Effect of, a) ionic strength $(I)$ and, b) dielectric constant $(D)$ of the medium on the rate of paladium(II)-catalyzed oxidation of L-tryptophan by hexacyanoferrate(III) in perchloric acid medium. [Trp] $=0.01,[\mathrm{HCF}]=7.0 \times 10^{-4},\left[\mathrm{H}^{+}\right]=2.0$ and $\left[\mathrm{Pd}^{\mathrm{II}}\right]=5.0 \times 10^{-5} \mathrm{~mol} \mathrm{dm}{ }^{-3}$ at $25^{\circ} \mathrm{C}$. 

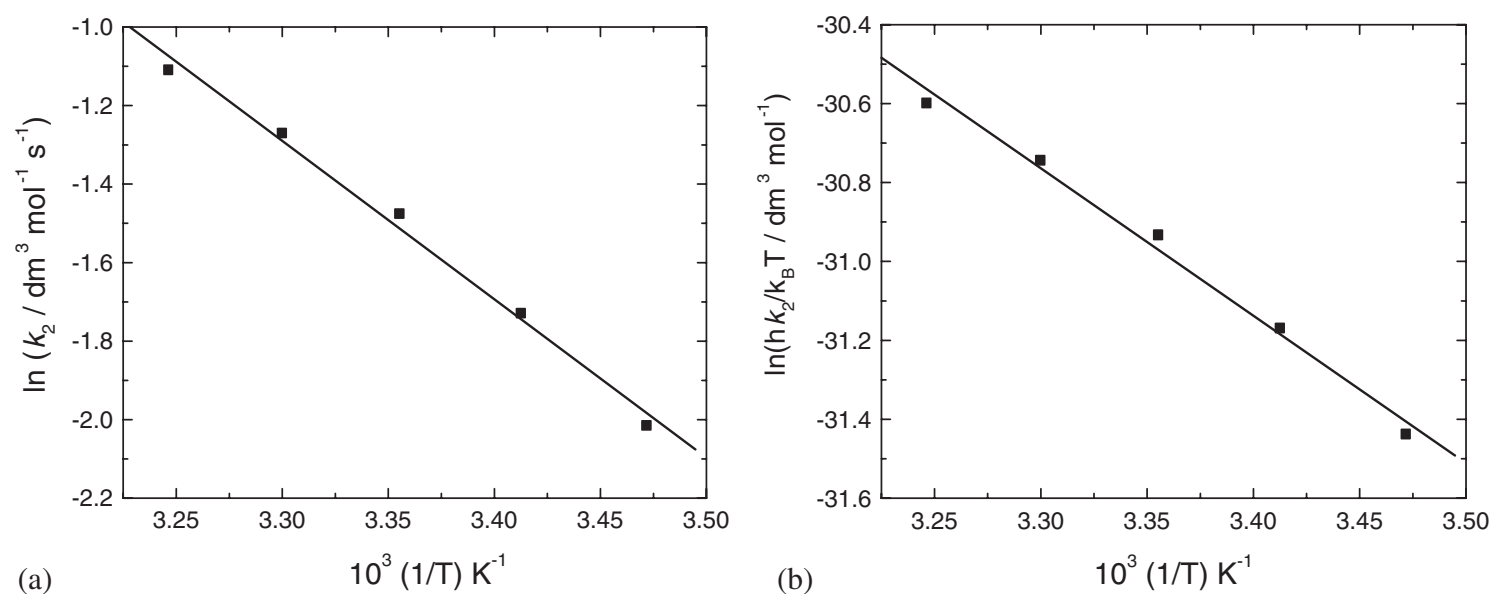

Figure 6. (a) Arrhenius and, (b) Eyring plots in the palladium(II)-catalyzed oxidation of L-tryptophan by hexacyanoferrate(III) in perchloric acid medium. $[\mathrm{Trp}]=0.01,[\mathrm{HCF}]=7.0 \times 10^{-4},\left[\mathrm{H}^{+}\right]=2.0,\left[\mathrm{Pd}^{\mathrm{II}}\right]=$ $5.0 \times 10^{-5}$ and $I=3.0 \mathrm{~mol} \mathrm{dm}^{-3}$.

Table 2. Activation parameters of the second order rate constant $k_{2}$ in the palladium(II)-catalyzed oxidation of L-tryptophan by hexacyanoferrate(III) in perchloric acid medium. $[\mathrm{Trp}]=0.01,[\mathrm{HCF}]=7.0 \times 10^{-4},\left[\mathrm{H}^{+}\right]=2.0,\left[\mathrm{Pd}^{\mathrm{II}}\right]=5.0$ $\times 10^{-5}$ and $I=3.0 \mathrm{~mol} \mathrm{dm}^{-3}$.

\begin{tabular}{lccc}
\hline$\Delta S^{\neq}, \mathrm{J} \mathrm{mol}^{-1} \mathrm{~K}^{-1}$ & $\Delta H^{\neq}, \mathrm{kJ} \mathrm{mol}^{-1}$ & $\Delta G_{298}^{\neq}, \mathrm{kJ} \mathrm{mol}^{-1}$ & $E_{\mathrm{a}}^{\neq}, \mathrm{kJ} \mathrm{mol}^{-1}$ \\
\hline-152.98 & 31.04 & 76.63 & 33.54 \\
\hline
\end{tabular}

Experimental error $\pm 4 \%$

the reactants and ionic strength. The obtained results indicate that the pseudo-first order rate constant $k_{\mathrm{C}}$ was increased with raising temperature. The activation parameters of the second order rate constant, $k_{2}\left(k_{2}=\right.$ $k_{\mathrm{C}} /[\mathrm{Trp}]$ ), are calculated using Arrhenius, (figure 6a) and Eyring (figure 6b) plots and are listed in table 2.

\subsection{Behavior of L-tryptophan in acid media}

Martell and Smith ${ }^{40}$ reported that amino acids exist as zwitterions in neutral media and predominantly tend to protonate in acid media (Eq. (5) in scheme 1). The high concentration of hydrogen ion employed in the present reaction as well as the observed enhancement of the reaction rate upon increasing acid concentration suggesting protonation of L-tryptophan in a preequilibrium step and its protonated form $\left(\operatorname{Trp}^{+}\right)$appears to be the reactive species in the rate-determining step.

\subsection{Behavior of hexacyanoferrate(III) in acid media}

In perchloric acid media, hexacyanoferrate(III) forms different protonated species as shown in the equilibria (2)-(4) with the stability constants: $\beta_{1}=K_{1}, \beta_{2}=$
$K_{1} K_{2}$ and $\beta_{3}=K_{1} K_{2} K_{3}$ belonging to the species with one, two and three protons, respectively. ${ }^{41}$

$$
\begin{aligned}
& {\left[\mathrm{Fe}(\mathrm{CN})_{6}\right]^{3-}+\mathrm{H}^{+} \stackrel{K_{1}}{=} \mathrm{H}\left[\mathrm{Fe}(\mathrm{CN})_{6}\right]^{2-}} \\
& \mathrm{H}\left[\mathrm{Fe}(\mathrm{CN})_{6}\right]^{2-}+\mathrm{H}^{+} \stackrel{K_{2}}{=} \mathrm{H}_{2}\left[\mathrm{Fe}(\mathrm{CN})_{6}\right]^{-} \\
& \mathrm{H}_{2}\left[\mathrm{Fe}(\mathrm{CN})_{6}\right]^{-}+\mathrm{H}^{+} \stackrel{K_{3}}{=} \mathrm{H}_{3}\left[\mathrm{Fe}(\mathrm{CN})_{6}\right]
\end{aligned}
$$

where $K_{3}<K_{2}<K_{1}<10$.

The existence of higher protonated complexes is ruled out as they exist at relatively higher $\left[\mathrm{H}^{+}\right] .{ }^{42}$ Thus, a single protonated ferricyanide, $\mathrm{H}\left[\mathrm{Fe}(\mathrm{CN})_{6}\right]^{2-}$, may be the reactive species in the present investigation.

\subsection{Behavior of palladium(II) species in acid media}

In most of the studies using palladium(II) as a homogenous catalyst, it has been employed in the form of palladium(II) chloride. It is important to know the probable species of palladium(II) chloride in acid media. The different possible mononuclear complexes of palladium(II) such as $\left[\mathrm{PdCl}_{3} \mathrm{~L}\right]^{-},\left[\mathrm{PdCl}_{2} \mathrm{~L}_{2}\right],\left[\mathrm{PdClL}_{3}\right]^{+}$and $\left[\mathrm{PdL}_{4}\right]^{2+}$ (where $\mathrm{L}$ represents a ligand like amine, 
phosphine, sulphide) are reported. ${ }^{43}$ It is dissolved in the presence of $\mathrm{Cl}^{-}$. Elding ${ }^{44}$ reported that in the presence of chloride ion, palladium(II) chloride exists as $\left[\mathrm{PdCl}_{4}\right]^{2-}$ and in the aqueous solution, it may be further hydrolyzed to $\left[\mathrm{PdCl}_{3}\left(\mathrm{H}_{2} \mathrm{O}\right)\right]^{-}$.

\subsection{Reaction mechanism}

The hexacyanoferrate(III) oxidation of L-tryptophan occurs in measurable quantities in the presence of small amounts of palladium(II) catalyst in perchloric acid medium. The reaction has a stoichiometry of $2: 1$, i.e., two moles of hexacyanoferrate(III) requires one mole of L-tryptophan. The order with respect to [HCF] was found to be unity and less than unity each with respect to both $[\mathrm{Trp}]$ and $\left[\mathrm{Pd}^{\mathrm{II}}\right]$. As $\left[\mathrm{H}^{+}\right]$increases, the reaction rate also increases with fractional-second order dependence suggesting protonation of both Ltryptophan and hexacyanoferrate(III). The rate is not considerably affected by $\mathrm{HCF}$ (II) suggesting that the probability of any fast equilibrium with the product preceding the rate-determining step was ruled out. The rate-determining step should be irreversible as is generally the case for one electron oxidants ${ }^{45}$ and the oxidation takes place through generation of a free radical

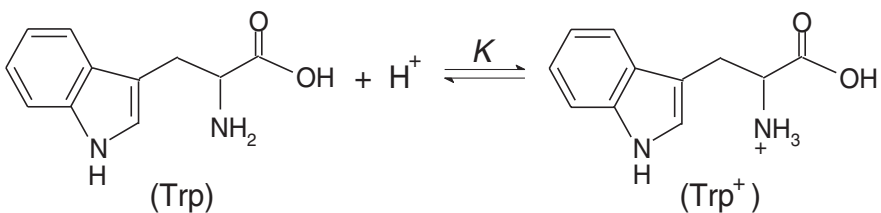

$\left[\mathrm{Fe}(\mathrm{CN})_{6}\right]^{3-}+\mathrm{H}^{+} \stackrel{K_{1}}{\rightleftharpoons} \mathrm{H}\left[\mathrm{Fe}(\mathrm{CN})_{6}\right]^{2-}$
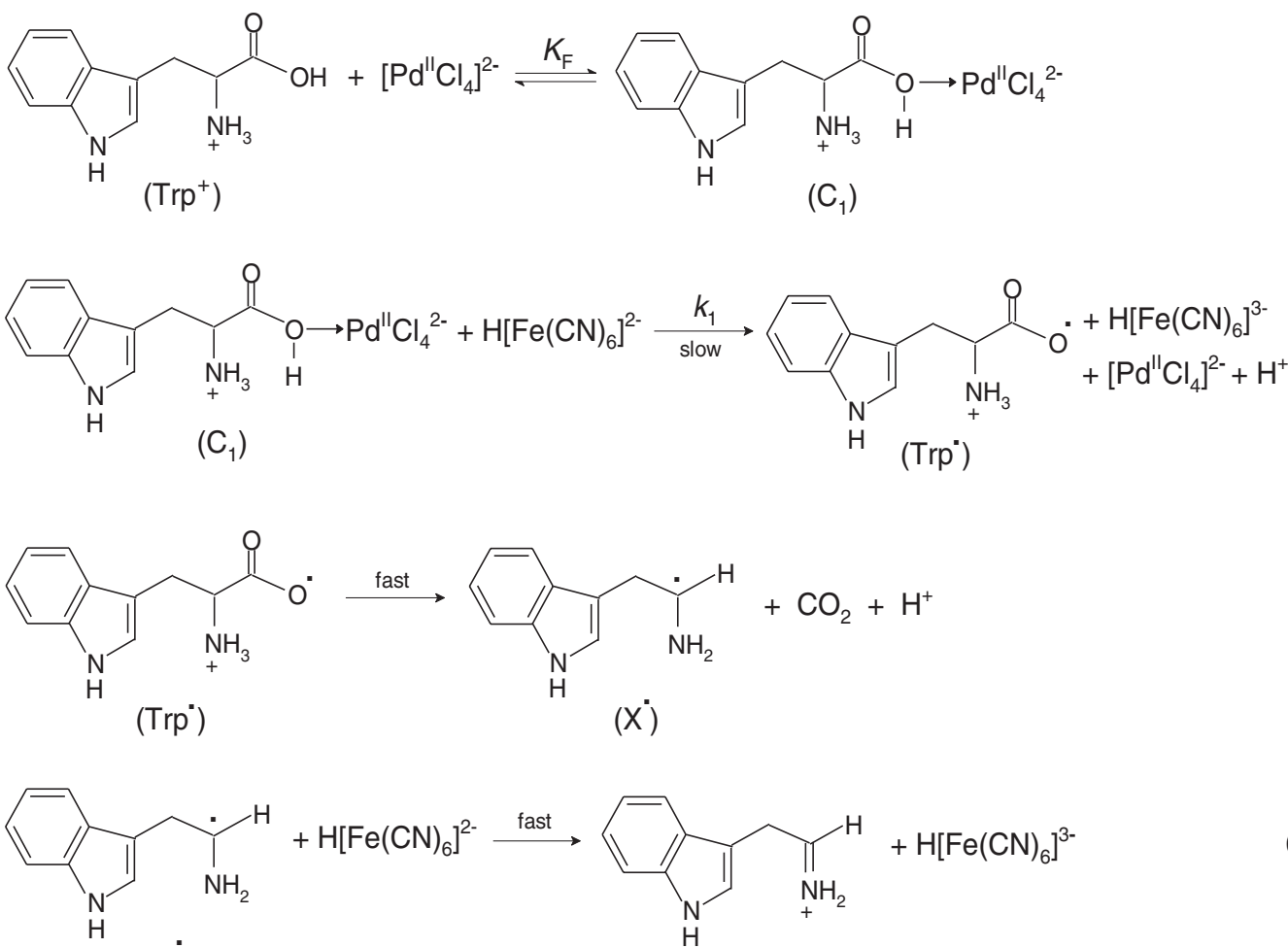

(X)

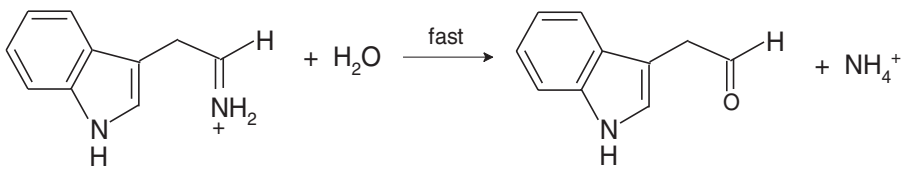

Scheme 1. Mechanism of palladium(II)-catalyzed oxidation of L-tryptophan by hexacyanoferrate(III) in perchloric acid medium. 
as confirmed experimentally. The effect of ionic strength and dielectric constant on the reaction rate suggests that similarly charged species are interacting in the rate-determining step. ${ }^{46}$

Based on the experimental results, the proposed mechanism (scheme 1) involves protonation of both L-tryptophan and hexacyanoferrate(III) followed by complexation of the protonated L-tryptophan with $\mathrm{Pd}^{\mathrm{II}}$ species, $\left[\mathrm{PdCl}_{4}\right]^{2-}$, to form an adduct $\mathrm{C}_{1}$ prior to the rate-determining step. It is reported $\mathrm{d}^{5-7}$ that amino acids form adducts with some transition metal ions owing to the availability of electron pair on oxygen atom of the carboxylate group. Within protolytic amino acid system, there are carboxylate and amine groups which may act as nucleophiles, depending on the $\mathrm{pH}$ of the medium. The protolytic group with the highest basicity interacts with the transition metal ion. Thus, at low $\mathrm{pH}$, where the amine group is protonated, the carboxylate group should be able to attack the metal ion. Complex formation was proved spectrophotometrically as shown in figure 1a-c as well as kinetically by the nonzero intercept of the plot $\left[\mathrm{Pd}^{\mathrm{II}}\right] / k_{\mathrm{C}}$ versus $1 /[\mathrm{Trp}]$ (figure 7). Such a complex between amino acid and palladium(II) catalyst has been reported in earlier studies. ${ }^{47}$ Then, the active species of the oxidant, $\mathrm{H}\left[\mathrm{Fe}(\mathrm{CN})_{6}\right]^{2-}$, attacks the formed intermediate complex in a slow (ratedetermining) step to yield L-tryptophan free radical and $\mathrm{HCF}$ (II) with regeneration of the catalyst $\mathrm{Pd}^{\mathrm{II}}$. This is followed by decarboxylation of L-tryptophan free

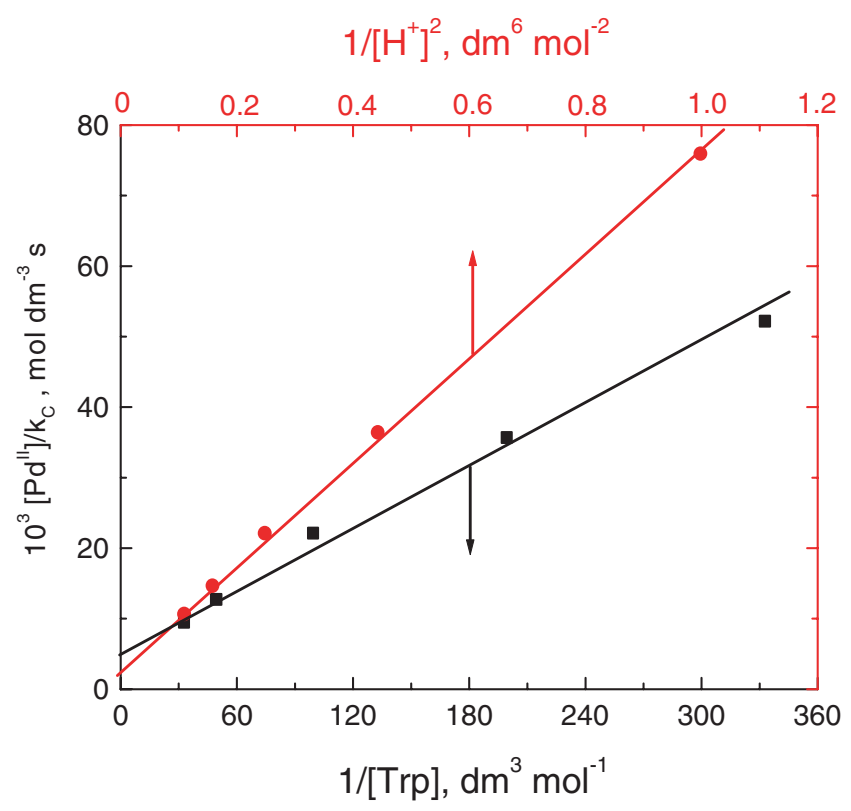

Figure 7. Verification of the rate law (17) in the form of Eq. (19) in the palladium(II)-catalyzed oxidation of L-tryptophan by hexacyanoferrate(III) in perchloric acid medium. $[\mathrm{HCF}]=7.0 \times 10^{-4}$ and $I=3.0 \mathrm{~mol} \mathrm{dm}^{-3}$ at $25^{\circ} \mathrm{C}$.

radical forming a new radical intermediate $(\mathrm{X} \cdot)$. The latter reacts with another $\mathrm{H}\left[\mathrm{Fe}(\mathrm{CN})_{6}\right]^{2-}$ species in a subsequent fast step to give rise to the final oxidation products.

The suggested mechanism leads to the following rate law (see Appendix),

$$
\begin{gathered}
\text { Rate }=\frac{k_{1} K K_{1} K_{\mathrm{F}}[\operatorname{Tr} p]\left[\mathrm{Fe}(\mathrm{CN})_{6}^{3-}\right]\left[\mathrm{H}^{+}\right]^{2}\left[\mathrm{Pd}^{\mathrm{II}}\right]}{1+K\left[\mathrm{H}^{+}\right]+K_{1}\left[\mathrm{H}^{+}\right]+K K_{1}\left[\mathrm{H}^{+}\right]^{2}+K K_{\mathrm{F}}[\operatorname{Trp}]\left[\mathrm{H}^{+}\right]+K K_{1} K_{\mathrm{F}}[\operatorname{Trp}]\left[\mathrm{H}^{+}\right]^{2}} \\
k_{\mathrm{C}}=\frac{k_{1} K K_{1} K_{\mathrm{F}}[\operatorname{Trp}]\left[\mathrm{H}^{+}\right]^{2}\left[\mathrm{Pd}^{\mathrm{II}}\right]}{\left[\mathrm{Fe}(\mathrm{CN})_{6}^{3-}\right]}=\frac{k_{\mathrm{F}}[\operatorname{Trp}]\left[\mathrm{H}^{+}\right]+K K_{1} K_{\mathrm{F}}[\operatorname{Trp}]\left[\mathrm{H}^{+}\right]^{2}}{\left.1+K\left[\mathrm{H}^{+}\right]+K_{1}\left[\mathrm{H}^{+}\right]+K \mathrm{H}^{+}\right]^{2}+K K_{\mathrm{F}}\left[{ }^{2}\right.}
\end{gathered}
$$

Equation (13) can be rearranged to the following form, which is suitable for verification:

$\frac{\left[\mathrm{Pd}^{\mathrm{II}}\right]}{k_{\mathrm{C}}}=\left(\frac{1+m}{k_{1} K K_{1} K_{\mathrm{F}}\left[\mathrm{H}^{+}\right]^{2}}\right) \frac{1}{[\operatorname{Trp}]}+\frac{1}{k_{1} K_{1}\left[\mathrm{H}^{+}\right]}+\frac{1}{k_{1}}$

where, $m=\left[\mathrm{H}^{+}\right]\left(K+K_{1}+K K_{1}\left[\mathrm{H}^{+}\right]\right)$.

According to Eq. (14), other conditions being constant, plots of $\left[\mathrm{Pd}^{\mathrm{II}}\right] / k_{\mathrm{C}}$ versus $1 /[\mathrm{Trp}]$ and $\left[\mathrm{Pd}^{\mathrm{II}}\right] / k_{\mathrm{C}}$ versus $1 /\left[\mathrm{H}^{+}\right]^{2}$ should be linear which were found to be so (figure 7).

Activation parameters listed in table 2 may be discussed as follows. The observed large negative values of $\Delta S^{\neq}$confirms the compactness of the formed L-tryptophan-palladium(II) adduct and such activated adduct is more ordered than the reactants due to loss of degree of freedom. ${ }^{48}$ The experimental values of $\Delta H^{\neq}$ and $\Delta S^{\neq}$were both favorable for electron transfer process. Again, the positive values of both $\Delta H^{\neq}$and $\Delta G^{\neq}$indicate the endothermic formation of adduct and its non-spontaneity, respectively.

\section{Conclusions}

The reaction between L-tryptophan and hexacyanoferrate(III) in perchloric acid medium does not proceed in the absence of a catalyst and occurs in a significant rate in the presence of small amount of palladium(II) catalyst. The mode of electron transfer has been indicated through an adduct between L-tryptophan and palladium(II) catalyst via the carboxyl group rather than the amine group. The overall mechanistic sequence described here is consistent with the experimental results and product analysis. 


\section{Appendix}

Derivation of rate law:

According to the suggested mechanism and regarding to reaction (8),

$$
\text { Rate }=\frac{-d\left[\mathrm{Fe}(\mathrm{CN})_{6}^{3-}\right]}{d t}=k_{1}[\mathrm{C}]\left[\mathrm{HFe}(\mathrm{CN})_{6}^{2-}\right]
$$

from reactions (6)-(8)

$$
K=\frac{\left[\operatorname{Trp}^{+}\right]}{[\operatorname{Trp}]\left[\mathrm{H}^{+}\right]},\left[\operatorname{Trp}^{+}\right]=K[\operatorname{Trp}]\left[\mathrm{H}^{+}\right]
$$

and

$$
\begin{aligned}
K_{1} & =\frac{\left[\mathrm{HFe}(\mathrm{CN})_{6}^{2-}\right]}{\left[\mathrm{Fe}(\mathrm{CN})_{6}^{3-}\right]\left[\mathrm{H}^{+}\right]},\left[\mathrm{HFe}(\mathrm{CN})_{6}^{2-}\right] \\
& =K_{1}\left[\mathrm{Fe}(\mathrm{CN})_{6}^{3-}\right]\left[\mathrm{H}^{+}\right] \\
K_{\mathrm{F}} & =\frac{[\mathrm{C}]}{\left[\operatorname{Trp}^{+}\right]\left[\mathrm{Pd}^{\mathrm{II}}\right]},[\mathrm{C}]=K_{\mathrm{F}}\left[\operatorname{Trp}^{+}\right]\left[\mathrm{Pd}^{\mathrm{II}}\right] \\
& =K K_{\mathrm{F}}[\operatorname{Trp}]\left[\mathrm{H}^{+}\right]\left[\mathrm{Pd}^{\mathrm{II}}\right]
\end{aligned}
$$

Substituting Eqs. (17) and (18) into Eq. (15) leads to,

$$
\text { Rate }=k_{1} K K_{1} K_{\mathrm{F}}[\operatorname{Trp}]\left[\mathrm{Fe}(\mathrm{CN})_{6}^{3-}\right]\left[\mathrm{H}^{+}\right]^{2}\left[\mathrm{Pd}^{\mathrm{II}}\right]
$$

The total concentration of Trp is given by:

$$
[\operatorname{Trp}]_{\mathrm{T}}=[\operatorname{Trp}]_{\mathrm{F}}+\left[\operatorname{Trp}^{+}\right]+[\mathrm{C}]
$$

where ' $\mathrm{T}$ ' and ' $\mathrm{F}$ ' stand for total and free concentrations.

Substituting Eqs. (16) and (18) into Eq. (20) and rearrangement gives,

$$
\begin{gathered}
{[\operatorname{Trp}]_{\mathrm{T}}=[\operatorname{Trp}]_{\mathrm{F}}+K[\operatorname{Trp}]\left[\mathrm{H}^{+}\right]} \\
+K K_{\mathrm{F}}[\operatorname{Trp}]\left[\mathrm{H}^{+}\right]\left[\mathrm{Pd}^{\mathrm{II}}\right] \\
{[\operatorname{Trp}]_{\mathrm{T}}=[\operatorname{Trp}]_{\mathrm{F}}\left(1+K\left[\mathrm{H}^{+}\right]+K K_{\mathrm{F}}\left[\mathrm{H}^{+}\right]\left[\mathrm{Pd}^{\mathrm{II}}\right]\right)}
\end{gathered}
$$

Therefore,

$$
[\operatorname{Trp}]_{\mathrm{F}}=\frac{[\operatorname{Trp}]_{\mathrm{T}}}{1+K\left[\mathrm{H}^{+}\right]+K K_{\mathrm{F}}\left[\mathrm{H}^{+}\right]\left[\mathrm{Pd}^{\mathrm{II}}\right]}
$$

In view of the low concentration of $\mathrm{Pd}^{\mathrm{II}}$, the third denominator term $K K_{\mathrm{F}}\left[\mathrm{H}^{+}\right]\left[\mathrm{Pd}^{\mathrm{II}}\right]$ in the above equation is neglected. Therefore,

$$
[\operatorname{Trp}]_{\mathrm{F}}=\frac{[\operatorname{Trp}]_{\mathrm{T}}}{1+K\left[\mathrm{H}^{+}\right]}
$$

Also,

$$
\left[\mathrm{Fe}(\mathrm{CN})_{6}^{3-}\right]_{\mathrm{T}}=\left[\mathrm{Fe}(\mathrm{CN})_{6}^{3-}\right]_{\mathrm{F}}+\left[\mathrm{HFe}(\mathrm{CN})_{6}^{2-}\right]
$$

Substituting Eq. (17) into Eq. (25),

$$
\left.\left[\mathrm{Fe}(\mathrm{CN})_{6}^{3-}\right]_{\mathrm{T}}=\left[\mathrm{Fe}(\mathrm{CN})_{6}^{3-}\right]_{\mathrm{F}}\left(1+K_{1}\right]\left[\mathrm{H}^{+}\right]\right)
$$

Therefore,

$$
\left[\mathrm{Fe}(\mathrm{CN})_{6}^{3-}\right]_{\mathrm{F}}=\frac{\left[\mathrm{Fe}(\mathrm{CN})_{6}^{3-}\right]_{\mathrm{T}}}{1+K_{1}\left[\mathrm{H}^{+}\right]}
$$

Similarly,

$$
\left[\mathrm{Pd}^{\mathrm{II}}\right]_{\mathrm{T}}=\left[\mathrm{Pd}^{\mathrm{II}}\right]_{\mathrm{F}}+[\mathrm{C}]
$$

Substituting Eq. (18) into Eq. (28) and rearrangement gives,

$$
\begin{gathered}
{\left[\mathrm{Pd}^{\mathrm{II}}\right]_{\mathrm{T}}=\left[\mathrm{Pd}^{\mathrm{II}}\right]_{\mathrm{F}}\left(1+K K_{\mathrm{F}}[\operatorname{Trp}]\left[\mathrm{H}^{+}\right]\right)} \\
{\left[\mathrm{Pd}^{\mathrm{II}}\right]_{\mathrm{F}}=\frac{\left[\mathrm{Pd}^{\mathrm{II}}\right]_{\mathrm{T}}}{1+K K_{\mathrm{F}}[\operatorname{Trp}]\left[\mathrm{H}^{+}\right]}}
\end{gathered}
$$

In view of the high concentrations of $\left[\mathrm{H}^{+}\right]$,

$$
\left[\mathrm{H}^{+}\right]_{\mathrm{T}}=\left[\mathrm{H}^{+}\right]_{\mathrm{F}}
$$

Substituting Eqs. (24), (27), (30) and (31) into Eq. (19) (and omitting 'T' and 'F' subscripts) leads to,

$$
\text { Rate }=\frac{k_{1} K K_{1} K_{\mathrm{F}}[\operatorname{Trp}]\left[\mathrm{Fe}(\mathrm{CN})_{6}^{3-}\right]\left[\mathrm{H}^{+}\right]^{2}\left[\mathrm{Pd}^{\mathrm{II}}\right]}{\left(1+K\left[\mathrm{H}^{+}\right]\right)\left(1+K_{1}\left[\mathrm{H}^{+}\right]\right)\left(1+K K_{\mathrm{F}}[\operatorname{Trp}]\left[\mathrm{H}^{+}\right]\right)}
$$

$$
\begin{aligned}
\text { Rate }= & \frac{k_{1} K K_{1} K_{\mathrm{F}}[\operatorname{Trp}]\left[\mathrm{Fe}(\mathrm{CN})_{6}^{3-}\right]\left[\mathrm{H}^{+}\right]^{2}\left[\mathrm{Pd}^{\mathrm{II}}\right]}{1+K\left[\mathrm{H}^{+}\right]+K_{1}\left[\mathrm{H}^{+}\right]+K K_{1}\left[\mathrm{H}^{+}\right]^{2}+K K_{\mathrm{F}}[\operatorname{Trp}]\left[\mathrm{H}^{+}\right]+K K_{1} K_{\mathrm{F}}[\operatorname{Trp}]\left[\mathrm{H}^{+}\right]^{2}+K^{2} K_{\mathrm{F}}[\operatorname{Trp}]\left[\mathrm{H}^{+}\right]^{2}} \\
& +K^{2} K_{1} K_{\mathrm{F}}[\operatorname{Trp}]\left[\mathrm{H}^{+}\right]^{3}
\end{aligned}
$$

The terms $K^{2} K_{\mathrm{F}}[\operatorname{Trp}]\left[\mathrm{H}^{+}\right]^{2}$ and $K^{2} K_{1} K_{\mathrm{F}}[\operatorname{Trp}]\left[\mathrm{H}^{+}\right]^{3}$ in the denominator of Eq. (33) are negligibly small compared to unity in view of the low concentration of Trp used. Therefore, Eq. (33) can be written as:

$$
\text { Rate }=\frac{k_{1} K K_{1} K_{\mathrm{F}}[\operatorname{Tr} \mathrm{p}]\left[\mathrm{Fe}(\mathrm{CN})_{6}^{3-}\right]\left[\mathrm{H}^{+}\right]^{2}\left[\mathrm{Pd}^{\mathrm{II}}\right]}{1+K\left[\mathrm{H}^{+}\right]+K_{1}\left[\mathrm{H}^{+}\right]+K K_{1}\left[\mathrm{H}^{+}\right]^{2}+K K_{\mathrm{F}}[\operatorname{Trp}]\left[\mathrm{H}^{+}\right]+K K_{1} K_{\mathrm{F}}[\operatorname{Trp}]\left[\mathrm{H}^{+}\right]^{2}}
$$

Under pseudo-first order condition, the rate-law can be expressed by Eq. (35),

$$
\text { Rate }=\frac{-d\left[\mathrm{Fe}(\mathrm{CN})_{6}^{3-}\right]}{d t}=k_{\mathrm{C}}\left[\mathrm{Fe}(\mathrm{CN})_{6}^{3-}\right]
$$


Comparing Eqs. (34) and (35), the following relation-

ship is obtained,

$$
k_{\mathrm{C}}=\frac{k_{1} K K_{1} K_{\mathrm{F}}[\operatorname{Trp}]\left[\mathrm{H}^{+}\right]^{2}\left[\mathrm{Pd}^{\mathrm{II}}\right]}{1+K\left[\mathrm{H}^{+}\right]+K_{1}\left[\mathrm{H}^{+}\right]+K K_{1}\left[\mathrm{H}^{+}\right]^{2}+K K_{\mathrm{F}}[\operatorname{Trp}]\left[\mathrm{H}^{+}\right]+K K_{1} K_{\mathrm{F}}[\operatorname{Trp}]\left[\mathrm{H}^{+}\right]^{2}}
$$

and with rearrangement,

$$
\frac{\left[\mathrm{Pd}^{\mathrm{II}}\right]}{k_{\mathrm{C}}}=\left(\frac{1+m}{k_{1} K K_{1} K_{\mathrm{F}}\left[\mathrm{H}^{+}\right]^{2}}\right) \frac{1}{[\operatorname{Trp}]}+\frac{1}{k_{1} K_{1}\left[\mathrm{H}^{+}\right]}+\frac{1}{k_{1}}
$$

where,

$$
m=\left[H^{+}\right]\left(K+K_{1}+K K_{1}\left[\mathrm{H}^{+}\right]\right)
$$

\section{References}

1. Naik P N, Chimatadar S A and Nandibewoor S T 2008 Transition Met. Chem. 33405

2. Yathirajan H S, Raju C R, Mohana K N, Sheena S and Padmarajaiah N 2003 Turk. J. Chem. 27571

3. Sanjeevagowda T P, Mahantesh A A and Abdulazizkhan L H 2008 J. Solution Chem. 371795

4. Khalid M A A 2007 Arab. J. Sci. Eng. 33199

5. Fawzy A 2014 Transition Met. Chem. 39567

6. Fawzy A 2015 Int. J. Chem. Kinet. 471

7. Fawzy A and Asghar B H 2015 Transition Met. Chem. 40287

8. Fawzy A, Ashour S S and Musleh M A 2014 React. Kinet. Mech. Cat. 111443

9. Fawzy A, Ashour S S and Musleh M A 2014 Int. J. Chem. Kinet. 46370

10. Fawzy A, Ashour S S, Musleh M A, Hassan R M and Asghar B H 2015 (doi: 10.1016/j.jscs.2014.10.003) (in press) J. Saudi Chem. Soc.

11. Shetti N P, Hosamani R R and Nandibewoor S T 2009 Open Cat. J. 2130

12. Shetti N P, Hosamani R R and Nandibewoor S T 2008 Int. J. Inorg. Chem. 144

13. Shetti N P and Nandibewoor S T 2009 Z. Phys. Chem. 233299

14. Kabir-ud-Din Altaf M and Akram M 2008 J. Disper. Sci. Technol. 29809

15. Prabhu P, Babu R S and Narayanan S S 2011 Coll. Surf. B: Biointerf. 87103

16. Anweting I P, Iyun J F and Idris S O 2012 Adv. Appl. Sci. Res. 33401

17. Sharanabasamma K, Angadi M A, Salunke M S and Tuwar S M 2009 Ind. Eng. Chem. Res. 4810381

18. Goel A and Sharma S 2010 Transition Met. Chem. 35 549

19. Kelson E P and Phengsy P P 2000 Int. J. Chem. Kinet. 32760

20. Speakman P T and Waters W A 1955 J. Chem. Soc. 40

21. Jose T P, Nandibewoor S T and Tuwar S M $2006 \mathrm{~J}$. Solution Chem. 3551

22. Singh V N, Singh M P and Saxena B B L 1970 Indian J. Chem. 8529

23. Leal J M, Garcia B and Domingo P L 1998 Coord. Chem. Rev. 17379
24. Tuwar S M, Nandibewoor S T and Raju J R 1991 Transition Met. Chem. 16335

25. Tandon P K, Mehrotra A, Srivatsava M, Dhusia M and Singh S B 2007 Transition Met. Chem. 3274

26. Dubey S, Sharma N, Khandalwal C L and Sharma P D 2003 Transition Met. Chem. 28176

27. Hiremath G A, Timmanagoudar P L and Nandibewoor S T 1998 React. Kinet Cat. Lett. 63403

28. Chimatadar S A, Salunke M S and Nandibewoor S T 2004 Transition Met. Chem. 29743

29. Chimatadar S A, Koujalagi S B and Nandibewoor S T 2001 Transition Met. Chem. 2762

30. Charles W J S and Wilkins R G 1980 Inorg. Chem. 19 3244

31. Jattinagoudar L N, Byadagi K S, Shirhatti N M, Nandibewoor S T and Chimatadar S A 2013 J. Chem. Pharm. Res. 5290

32. Badi S S and Tuwar S M 2013 J. Solution Chem. 421518

33. Day M C and Selbin J 1964 In Theoretical inorganic chemistry (New York: Reinhold Publishing Corporation) p. 226

34. Kapoor R C, Mehrotra R N, Vajpai S K and Chaudhary P 1991 Transition Met. Chem. 1665

35. Das A K 2001 Coord. Chem. Rev. 213307

36. Singh A K, Srivastava S, Srivastava J, Srivastava R and Singh P 2007 J. Mol. Cat. A 27872

37. Jeffery G H, Bassett J, Mendham J and Denney R C 1996 In Vogel's text book of quantitative chemical analysis 5th edn. (Essex: ELBS Longman) (a) p. 399 and (b) p. 384

38. Feigl F 1975 In Spot tests in organic analysis (New York: Elsevier) p. 195

39. Vogel A I 1973 In Text book of practical organic chemistry, 3rd edn ELBS (London: Longman) p. 332

40. Martell A E and Smith R M 1974 In Critical stability constants (New York: Plenum Press) vol. I, p. 321

41. Pedro L D, Begon D and Jose M L 1990 Can. J. Chem. 68228

42. Garcia B, Ruiz R and Leal J M 2008 J. Phys. Chem. A 1124921

43. Cotton F A and Wilkison G 1988 In Advanced inorganic chemistry, 5th edn. (New York: John Wiley \& Sons) p. 127

44. Elding L I 1972 Inorg. Chim. Acta 6647

45. Leal J M, Domingo P L, Garcla B and Ibeas S $1993 \mathrm{~J}$. Chem. Soc. Faraday Trans. 893571

46. (a) Stewart R 1965 In Oxidation in Organic Chemistry K B Wiberg (ed.) Part A (New York: Academic Press) p. 48; (b) Laidler K J 1965 In Chemical kinetics. (New York: McGraw-Hill) p. 51

47. Singh A K, Jain B, Katre R N Y and Singh S P 2009 Open Cat. J. 212

48. Weissberger A 1974 In Investigation of rates and mechanism of reactions in techniques of chemistry (New York: John Wiley \& Sons Interscience) p. 421 